\title{
UTLIZATION OF SHREDDING MACHINE TO PREPARE HAULM OF POTATTES ROW MATERIALS
}

\author{
FOUDA, T. Z. ${ }^{1}$, A. F. A. GHONIM. ${ }^{2}$, A. A. DRBALA ${ }^{1}$ and A. A. EL-RIES ${ }^{2}$ \\ 1. Agricultural Mechanization Department, Faculty of Agriculture, Tanta University. \\ 2. Agricultural Engineering Research Institute, $A R C$, Dokki Giza
}

(Manuscript received 6 August 2014)

\begin{abstract}
Is the potato crop vegetables Home in Egypt, which is cultivated annually in the lugs of the three (Winter ,Nile and Summer) total area within the limits of 450 thousand acres and estimated the haulm of potatoes for the area cultivated about 1,575 million tons with an average of about 3.5 tons per acre of haulm potato. Field crop residues have become a heavy problem of the Egyptian farmer. To get rid of this trouble, being resorted out burned in the open field. Where as some farmers use these as heels, as rich get fern it a media for spreading diseases. That causes environmental disaster and dangerous healthy problem. Potatoes haulm around $8-9 \%$ of the total residues (18-25 million tons annually).

The trails are conducted at Gemmza Research Station, ARC under the four levels of drum speed $(1000,1200,1400$, and 1600 $\mathrm{rpm}), \&(48$ and 68) number of knives and three feeding rates $(600,800$, and $1000 \mathrm{~kg} / \mathrm{h})$, to measure the mean weight length, fuel consumption, power consumed, energy-consuming and machine performance efficiency. The mean length cut weight between $(6.608$ and $10.627 \mathrm{~mm})$ resulted

This objective of this research is to identify the appropriate mean weight lengths suitable to submission to the different animals, either small animals such as rabbits, medium animal such as goats, sheep or large animals such as cows and buffaloes.
\end{abstract}

\section{INTRODUCTION}

Technological advancement in plant breeding for high yielding varieties and highly pest and disease resistant crop varieties has reached an advanced stage. But, commercialized agricultural production process may not be attained easily without the applications of modern farm machinery. Definition of crop residues, their types and harms affecting the environment, plants and humans, also the economic uses of these residues in agriculture, industry and, different used treatments were involved. ASAE Standards (1999) mentioned that agricultural wastes normally associated with the production and processing of food and fiber on farms, feed lots, ranches, ranges, and forests, which may include both animal manure and crop residues. Lewis (2000) mentioned that benefits that can be obtained through cutting include reduction of the bulk of fibrous materials for easier handling and transportation, attainment of 
relatively uniform product, product conversion into forms and different varieties of food desired by the consumers for various purposes from basic ingredients. Cutting makes the product more digestible, facilitates accurate mixing of ingredients and it is used as a pre-treatment for raw materials prior to canning, freezing and dehydration. It also helps to increase the rate of diffusion processes which occur in dehydration and solvent extraction. Radwan (2000) noted that the machine productivity increased from $508 \mathrm{~kg} / \mathrm{h}$ to $600 \mathrm{~kg} / \mathrm{h}$ for rice straw cutting. Awady et. al. (2001) stated that the quantities of crop residues in Egypt are estimated about 18.7 million ton/year, $53 \%$ of which (9.91 million ton) are directly burned. Also they mentioned that burning of cotton residues (1.24million ton/year) causes a loss of 532.000 equivalent ton of hydrocarbon fuel (1.806 million LE). (based on mean yield of 0.43 ton/fed). Potato Cultivation Egypt-Holland National Program (2001) indicated that the process of harvesting must be disposed of shoot the haulm, where this presence hinders the process of harvesting tubers.

\section{It should be noted that there are several ways to remove the haulm are:}

1- Manual method.

3- Thermal method.

2- Mechanical methods.

4- Chemical method haulm.

The best way to remove the mechanical method a free. Helmy et. al. (2003) stated that crop residues are considered the most critical problems facing the Egyptian farmer, especially after harvesting the crop. Egyptian farmers burn yearly about 2-3 ton/fed. Of rice straw and 5.87 million tons of corn stalks respectively as a means for disposing it and to save time for preparing the land of the next crop. Iya, (2005) improved and appropriate farm implements/machines are essential inputs in modern agricultural production processes. Thus, mechanization is used to describe the level of application of these inputs. Abdel-Mottaleb, and Obaia (2006) used hammer mill machine for milling the date palm leaves. They found that, the highest machine production of $508.6 \mathrm{~kg} / \mathrm{h}$ and machine efficiency of $92.5 \%$ was obtained at $4.80 \%$ w.b. leaves moisture content, drum speed of 1200 r.p.m and concave diameter of 22 $\mathrm{mm}$. While, the lowest energy requirements of $21.31 \mathrm{kw} . \mathrm{h} /$ ton was obtained at drum speed of 1000 r.p.m. and leaves moisture content of $15.36 \%$ w.b. On the other hands concave diameter of $11 \mathrm{~mm}$ showed the highest fineness degree of $71.7 \%$ at the range of $<11 \mathrm{~mm}$ at $4.80 \%$ w.b. leaves moisture content and drum speed of 1200 r.p.m. while the degree of fineness was greatly increased with the decreased of leaves moisture content and the increased of drum speed. Also,they mentioned that the crushed output of the plant residues were used in the manufacture of untraditional animal fodder and composite boards. Baiomy et. al., (2007), modified and tested locally manufactured chopping machine with cotton stalks, corn stalks and rice straw. 
The results were improved with cotton and corn stalks and the machine was successful with rice straw. El Khateeb (2008) indicated that, the increasing the cutter head speed from 22.1 to $35.3 \mathrm{~m} / \mathrm{s}$ at $35 \%$ mositure content decreasing the specific chopping energy from 2.91 to $2.7 \mathrm{kw}$.h/t El-Khateeb and EL-Keway (2012) developing of the performance of cutting knives in crop residues shredder. The maximum percentage of $<2 \mathrm{~cm}$ cutting length of $94.0 \%$ and $93.3 \%$ were obtained at cutting peed of $1500 \mathrm{rpm}$ and moisture content of $30 \%$ and $22.0 \%$ (w.b) for cotton stalks and rice straw respectively, The minimum value of useful power $1.10 \mathrm{KW}$ and $1.0 \mathrm{KW}$ were obtained at cutting speed of $900 \mathrm{rpm}$ and moisture content of $30 \%$ and $22.0 \%$ for cotton stalk and rice straw respectively. The unit energy from $(0.85 \& 1.50$ $\mathrm{KW} . \mathrm{h} / \mathrm{Mg})$ to $(0.80 \& 1.40 \mathrm{KW} . \mathrm{h} / \mathrm{Mg})$ with machine after modification at moisture content of $30.0 \%$ and $22.0 \%$ (w.b.) for cotton stalks and rice straw, respectively.

\section{MATERIALS AND METHODS}

In this work the chopping and crushing operation were carried out on haulm of potatoes during agricultural seasons, from 2010 to 2014 at Research Station of Gemmza.

\section{Materials}

\section{Machine:}

Figs (1) illustrated the specific at $\mathrm{mm}$ and dimensions of the main components of chopping and grinding equipment.

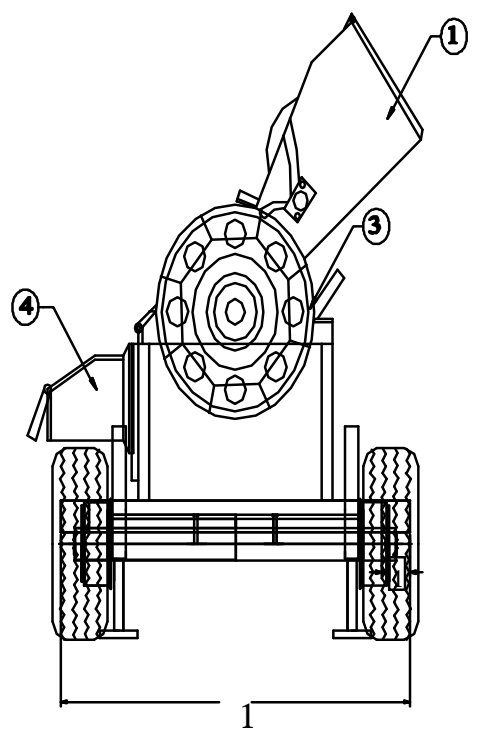

Side view. view.

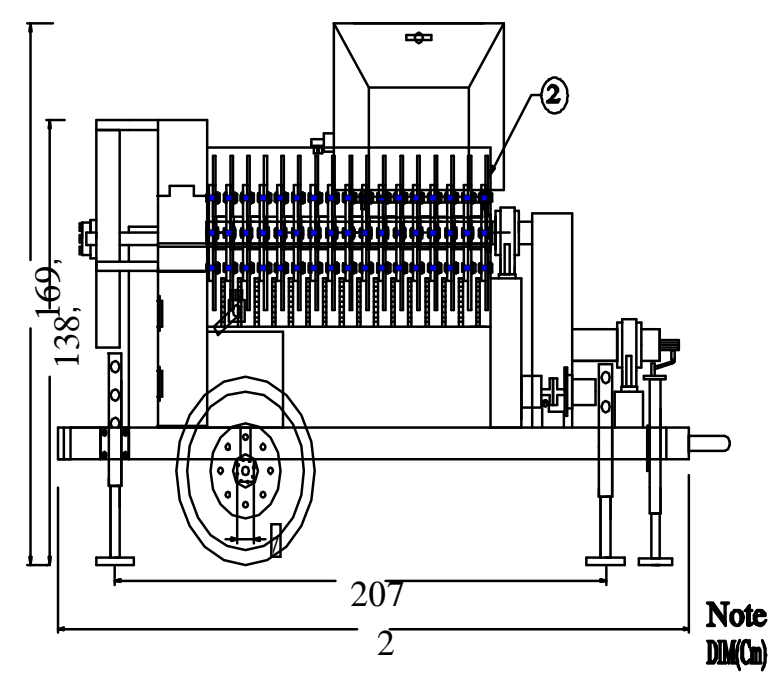

Elevation

1- Feeding orifice. 2- Knife. 3- Drum. 4- Excite gate. Fig. 1. Side view and elevation view of chopping and grinding equipment. 


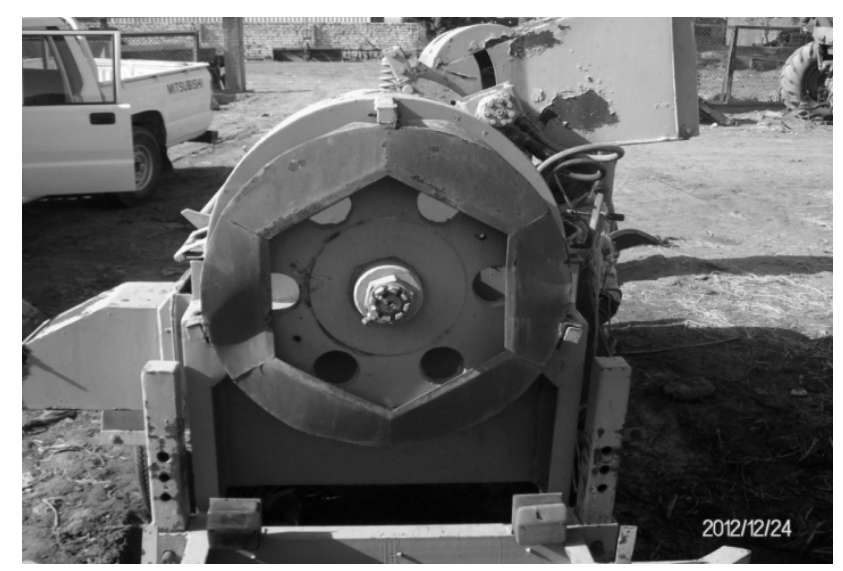

Fig. 2. Photograph for chopping and grinding equipment.

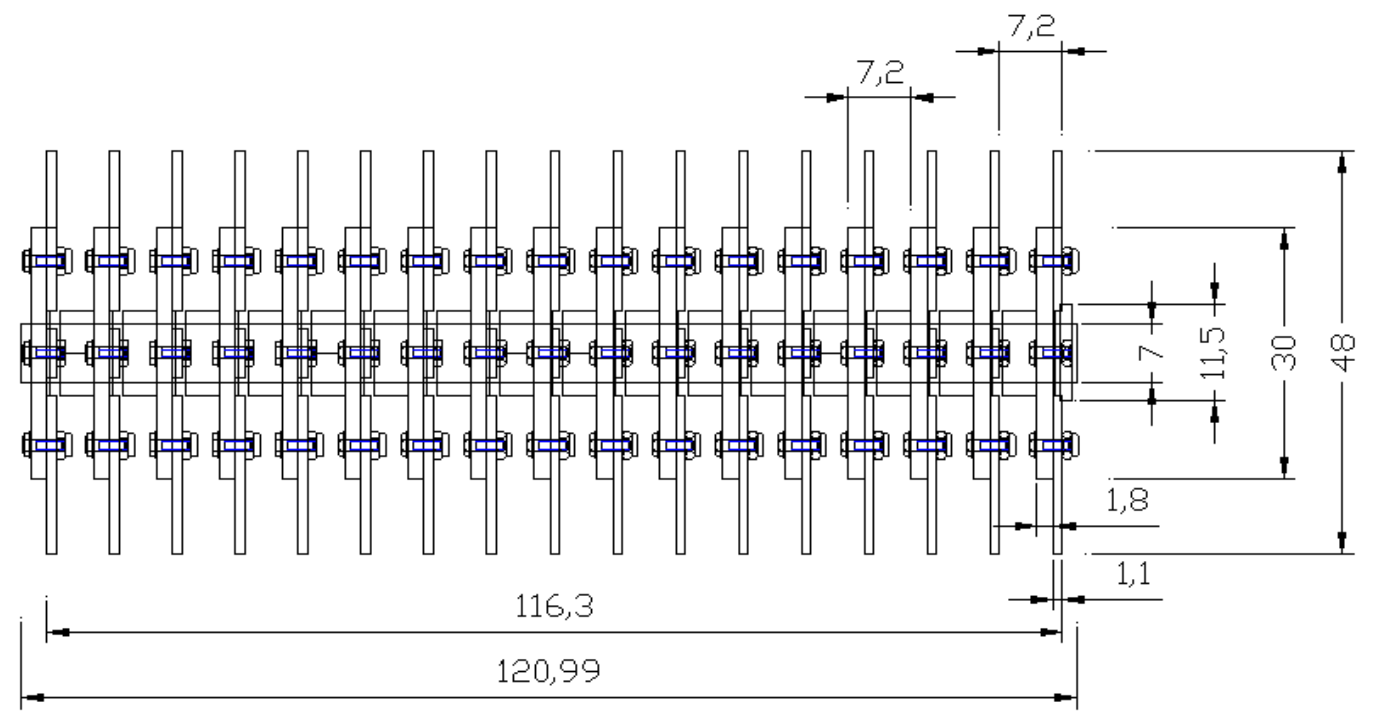

Fig. 3. The type of knives of chopping and grinding equipment. 


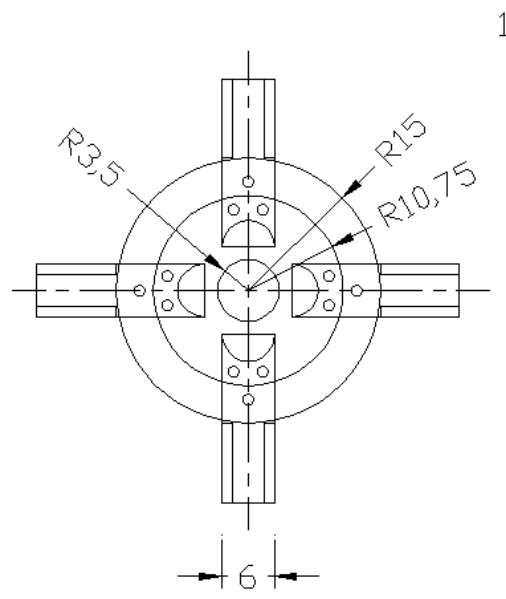

Cross section of chopping area

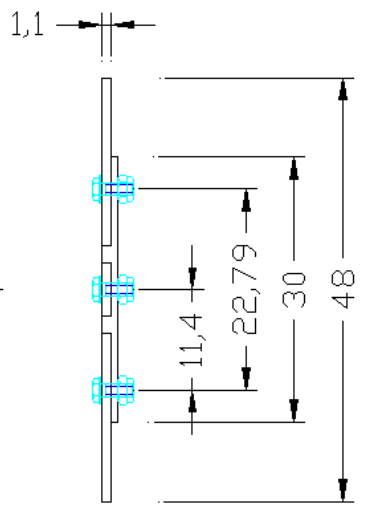

Elevation view

Fig. 4. Drum dimensions of fixed knives in the chopping -grinding chopper.

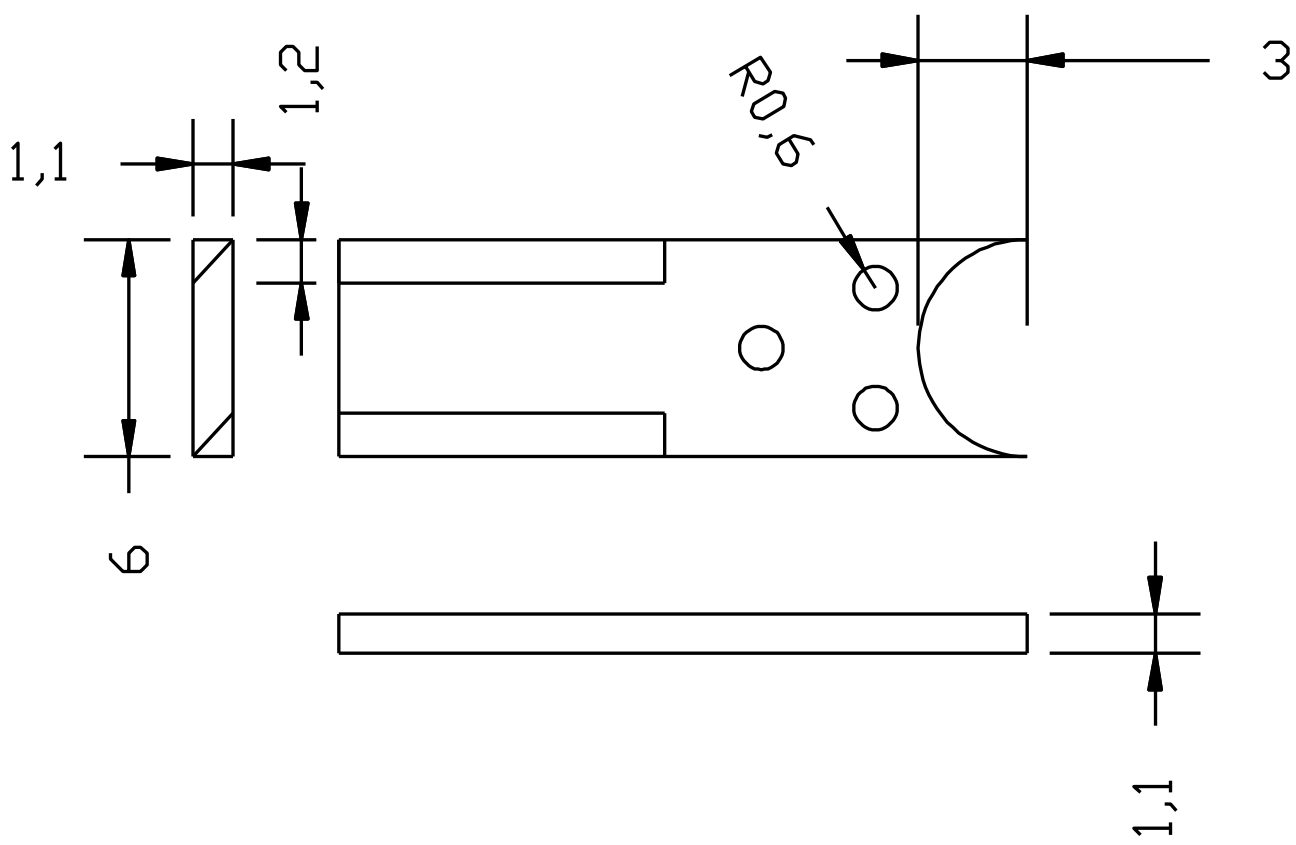

Fig. 5. Shape of the knife used the machine.

\section{Source of power:}

It is used tractor of $\mathrm{hp}$,(rw) The following treatments for the equipment are: Drum speeds: 1000, 1200, 1400 and 1600 rpm. , feeding rate: (600, 800, and 1000 $\mathrm{kg} / \mathrm{h}$ ) and number of knives: (48-68) knives are carried out to evaluate chopping machine.

Drum Speed: Specifications: Model 461895 Version 2.0 January 2004

Method of sample weight: Specifications: Model I10.( Tarek 2002) 
Using six sieves of square openings $(0.35,1,2,2.5,5$ and $10 \mathrm{~mm})$ with ANOVA analysis and classified. were used as the following:

- The sieve of opening size $0.35 \mathrm{~mm}$ fine materials grade $\mathrm{S}_{\mathrm{c} 1}$.

- The sieves of opening size $(1,2$ and $2.5 \mathrm{~mm})$ granular, small materials into three grades $\mathrm{S}_{\mathrm{C} 2}, \mathrm{~S}_{\mathrm{C} 3}, \mathrm{~S}_{\mathrm{C} 4}$.

- The sieves of opening size (5and $10 \mathrm{~mm}$ ) granular coarse material grade $\mathrm{S}_{\mathrm{c5}}$, $\mathrm{S}_{\mathrm{c} 6 \text {. }}$

- Materials do not pass through the opening size $10 \mathrm{~mm}$ considered as lump.

These measurements were carried out to determine the machine productivity and consumed power. (Ton/h.p.).

\section{Methods}

\section{Determination of production rate (Ton/ h.):}

The time of run of the experiment was measured by means of stop watch. The weight of input in the time to produce the output in ton per hour was determined.

\section{Determination of consumed power:}

Power consumption for every treatment was calculated by measuring the fuel consumed using the following formula (Hanna et. al. 1985):

Consumed power $=\mathrm{FC} \times \mathrm{F}^{\mathrm{s}} \times \mathrm{C} . \mathrm{V} . \times \frac{427}{750} \times 0.735$

$$
=4.18 \mathrm{Fc} \times \mathrm{F}^{\mathrm{s}} \times \mathrm{C} . \mathrm{V} . \mathrm{kw} \text {. }
$$

\section{Where:}

Fc : the fuel consumed, liter / sec., Fs : the fuel density kg. / lit.

C.V.: Calorific value of kcal / kg. $\quad$ 427: thermo-mechanical equivalent J / kcal.

\section{The mean weight length}

Analysis ten samples for each mixing ration. Weight screening materials for each sieve $\left(w_{1}, w_{2}, w_{3}, w_{4}, w_{5}\right.$ and $\left.w_{6}\right)$.

Calculated the size weight and its percentage for each sieve

Calculated mean size $\mathrm{mm}$ as the following:

Mean weight length $={ }^{1} \Sigma_{\mathrm{n}}\left[\mathrm{S}_{\mathrm{c} 1} \mathrm{~W}_{1}+\mathrm{S}_{\mathrm{c} 2} \mathrm{~W}_{2}+\mathrm{S}_{\mathrm{c} 3} \mathrm{~W}_{3}+\mathrm{S}_{\mathrm{c} 4} \mathrm{~W}_{4}+\mathrm{S}_{\mathrm{c} 5} \mathrm{~W}_{5}+\mathrm{S}_{\mathrm{c} 6} \mathrm{~W}_{6}\right] /{ }^{1} \Sigma_{\mathrm{n}} \mathrm{W}$.

\section{Power}

Estimated the consumed power to operate each machine by accurately measuring the fuel consumption immediately after executing each operation. The required energy was calculated by using the following formula:

Power $=\left(f_{c} \times 1 / 3600\right) \times P_{f} \times$ L.C.V. $\times 427 \times \varepsilon$ th $\times \varepsilon_{\varepsilon} m \times 1 / 75$. 


\section{Where:}

$\mathbf{F}_{\mathbf{c}}=$ Fuel consummation, (l/h.). $\mathbf{P}=$ density of the fuel, $\mathrm{kg} / \mathrm{l}$ (for Diesel fuel 0.85 $\mathrm{kg} / \mathrm{l})$.

L.C.V = calorific value of fuel, $\mathrm{Kcal} / \mathrm{kg}$. (Average

L.C.V. of Diesel-fuels $10,000 \mathrm{k} \mathrm{cal} / \mathrm{kg}$ ).

$\mathbf{4 2 7}=$ thermo mechanical equivalent, $\mathrm{kg} . \mathrm{m} / \mathrm{kcol}$., $\boldsymbol{\varepsilon}$ th $=$ thermal efficiency of the engine ( considered to be $40 \%$ for). , and $\varepsilon \mathbf{m}=$ mechanical efficiency of the diesel engine. (considered to be $80 \%$ for diesel engine).

\section{Productivety, ton/ $\mathbf{h}$.}

The productivity calculated as ratio between out put of machine and time consumed processed.

\section{Energy requirement, hp/ton.h}

The energy requirements for the cutting operation of different kind of plants, was calculated following estimated formula: power, hp /productivity, ton/h.

\section{Efficiency}

The efficiency calculated by using the formula:

Efficiency, \% = productivity, (ton/h) $* 1000 /$ feeding rate, $\mathrm{kg} / \mathrm{h}$.

\section{Cost analysis:}

Awady (1978): in the following from is used

THC $=(p / h)(i / a+i / 2+t+r)+(1.2 \times w \times s \times f)+m / 144$.

Where:

$$
\begin{aligned}
& \text { THC = total Hourly cost, } L E / h . \quad \quad \quad P=\text { purchase price of machine, } L E, \\
& \mathbf{h}=\text { working hours per year, } h / y r . ; \quad \mathbf{a}=\text { expected machine life, years. } \\
& \mathbf{i}=\text { interest rate, } 10 \% ; \quad \mathbf{t}=\text { taxes, } 3 \% ; \quad \mathbf{r}=\text { repair and maintenance }
\end{aligned}
$$

ratio, $5 \%$. $\quad \mathbf{w}=$ power, $\mathrm{Kw} . \quad \boldsymbol{s}=$ specific fuel consumption, L/Kw.h., $\mathbf{f}=$ fuel price, $L E / L, \mathbf{m}=$ operator monthly salary, $L E, 1.2$ is a factor to take care of oils, grease, etc. and $\mathbf{1 4 4}=$ is operator hours per month.

\section{RESULTS AND DISCUSSION}

The effects of drum speed, feeding rate, and number of knife on the mean weight length:

Data presented in Fig (6), shown that: By increasing mean weight length both (48 knifes) of drum speed and feeding rate increases consequently at $1000 \mathrm{rpm}$ drum speed and $600 \mathrm{~kg} / \mathrm{h}$ is recorded the lowest value of mean weight length of potato haulm $(0.661 \mathrm{~mm})$. On the other haulm the hightest of mean weight length $(1.060$ $\mathrm{mm}$ ) is monitorial at $1600 \mathrm{rpm}$ drum speed $1000 \mathrm{~kg} / \mathrm{h}$ feeding rate. Moreover, be changing the numbers of knives 48 knives to 64 knives, the results of the 
experimental trails are manifested steed the same trend by changing mean weight length according to the change of drum speed and feeding rate. So the lowest and highest values $(0.730 \mathrm{~mm} \& 1.063 \mathrm{~mm})$ at $600 \& 1000 \mathrm{~kg} / \mathrm{h}$ feeding rate, $1000 \& 1600$ rpm drum speed respectively. It is wealthy to mention this by increasing the number of knives at content loath of drum speed and feeding rate the mean weight lengths are increased.

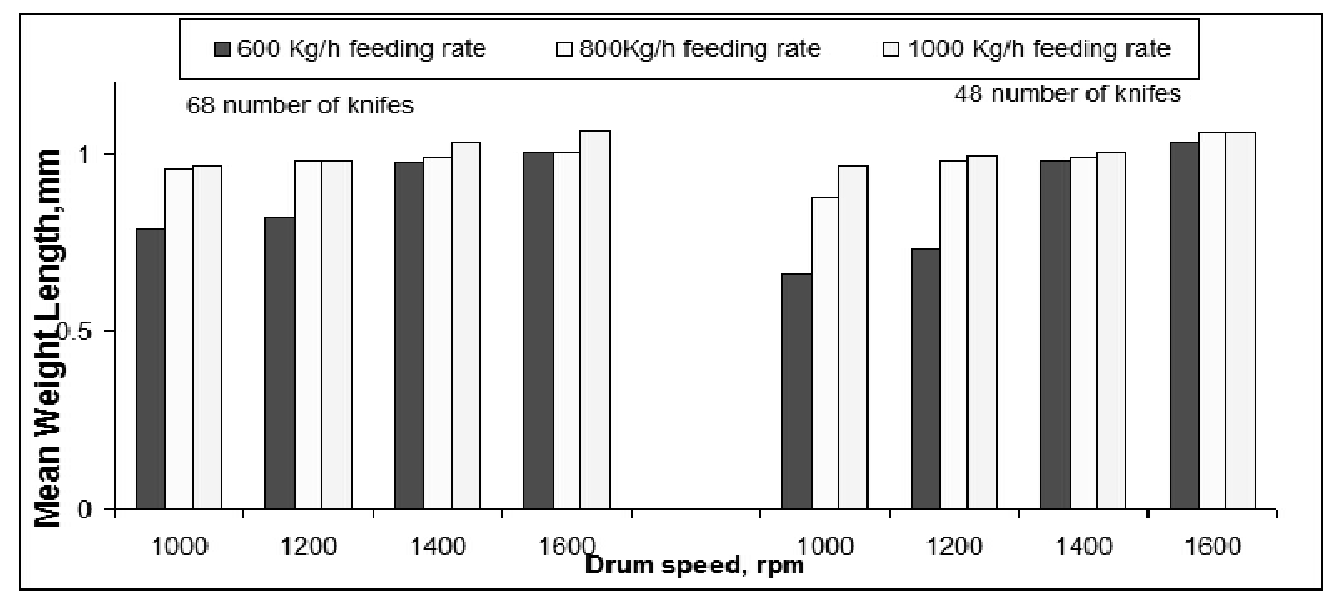

Fig. 6. The effect of drum speed, feeding rate and number of knives on the mean weight length.

The effects of drum speed, feeding rate, and number of knife on the productivity:

Fig (6) shows the effects of drum speed, feeding rate, and number of knife on the productivity. At (48) cutting knives and (600 \& 800 and $1000 \mathrm{~kg} / \mathrm{h}$ ) feeding rate, by increasing the drum speeds from (1000 to $1600 \mathrm{rpm})$, the machine productivity increased from ( 0.284 to 0.3990 .360 to 0.357 ton/h), and ( 0.437 to 0.357 ton/h) respectively. The pervious of changing trends are the same at (68) cutting knives and ( $600 \& 800 \&$ and $1000 \mathrm{~kg} / \mathrm{h}$ ) feeding rates, by increasing the drum speed from (1000 to $1600 \mathrm{rpm})$, the machine productivity increase from $(0.505$ to $0.532,0.461$ to 0.623 ton/h), and ( 0.496 to 0.737 ton/h) respectively.

From the revealed data, machine productivity is higher $(0.737 \mathrm{ton} / \mathrm{h})$ using drum speed (1600 rpm) and number of knife (68) and (1000 kg/h) feeding rate, Meanwhile the lowest productivity $(0.261 \mathrm{ton} / \mathrm{h})$ is at drum speed $1400 \mathrm{rpm}$ and number of knives 48 and $600 \mathrm{~kg} / \mathrm{h}$ feeding rate. 


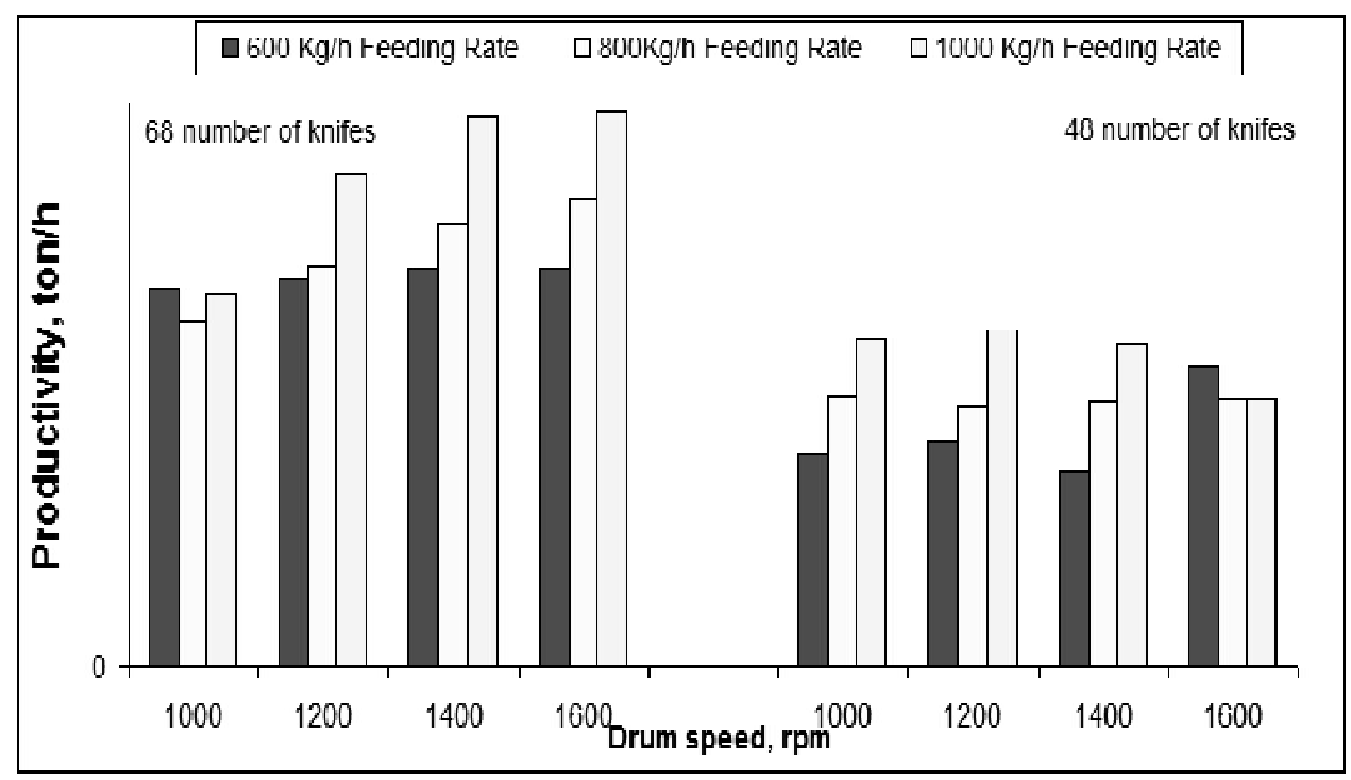

Fig. 7. The effect of drum speed feeding rate and number of knives on the productivity.

The effects of drum speed, feeding rate, and number of knife on the efficiency

Fig (7), shows the effects of drum speed, feeding rate, and number of knife on the efficiency at (48) cutting knives and (600 \& $800 \&$ and $1000 \mathrm{~kg} / \mathrm{h}$ ) feeding rate, by increasing the drum speed from (1000 to $1600 \mathrm{rpm}$ ), the machine efficiency increases from (92 to 95\%), decreased (89 to 95\%) and form (87 to 96\%) respectively.

The effects of drum speed, feeding rate, and number of knife on the efficiency at (68) cutting knives and $(600 \mathrm{~kg} / \mathrm{h})$ feeding rate, by increasing the drum speed from (1000 to $1600 \mathrm{rpm}$ ), the machine efficiency increased from (92 to $96 \% 91$ to $95 \%)$ and ( 87 to $93 \%$ ) respectively.

From the reveal data, machine efficiency is higher of (97\%) at drum speed $1400 \mathrm{rpm}$, number of knife 48 and $1000 \mathrm{~kg} / \mathrm{h}$ feeding rate, Meanwhile of lowest efficiency is $76 \%$ at drum speed $1400 \mathrm{rpm}$, number of knife 48 and $600 \mathrm{~kg} / \mathrm{h}$ feeding rate. By increasing the drum speed, the machine efficiency increased due to improving the cutting processes. 


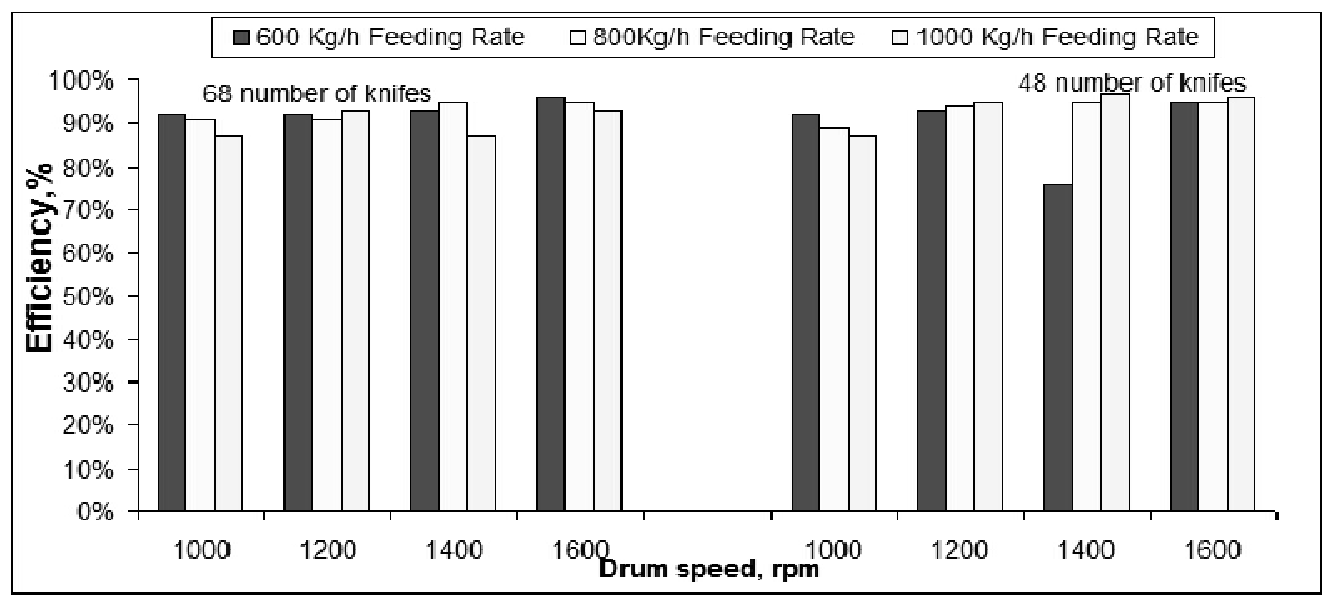

Fig. 8. The effect of drum speed feeding rate and number of knives on the efficiency.

The effects of drum speed, feeding rate, and number of knife on power requirement:

Fig (9) shows the effects of drum speed, feeding rate, and number of knives on the power requirement. At (48) cutting knives and (600 \&800 \& and $1000 \mathrm{~kg} / \mathrm{h}$ ) feeding rate, by increasing the drum speed from (1000 to $1600 \mathrm{rpm}$ ), the machine power requirement increases forms ( 25.778 to $28.794,27.971$ to $29.891,28.520$ to $30.714 \mathrm{hP}$ ), respectively. As the same the power requirement at (68) cutting knives and $(600 \& 800 \&$ and $1000 \mathrm{~kg} / \mathrm{h}$ ) feeding rate, by increasing the drum speed from (1000 to $1600 \mathrm{rpm})$, the machine power requirement increases form (25.229 to 29.068 , from 26.600 to 29.891 , from 27.313 to $30.439 \mathrm{HP}$ ), respectively. By increasing the drum speed, the machine power requirement increased due to improving the cutting processes.

From the relived data, machine power requirement was higher (30.714 HP) using drum speed (1600 rpm) and number of knife (48) and (1000 kg/h) feeding rate, meanwhile the lowest power requirement was (25.229 HP) using drum speed (1000 rpm) and number of knife (68) and (600 kg/h) feeding rate. 


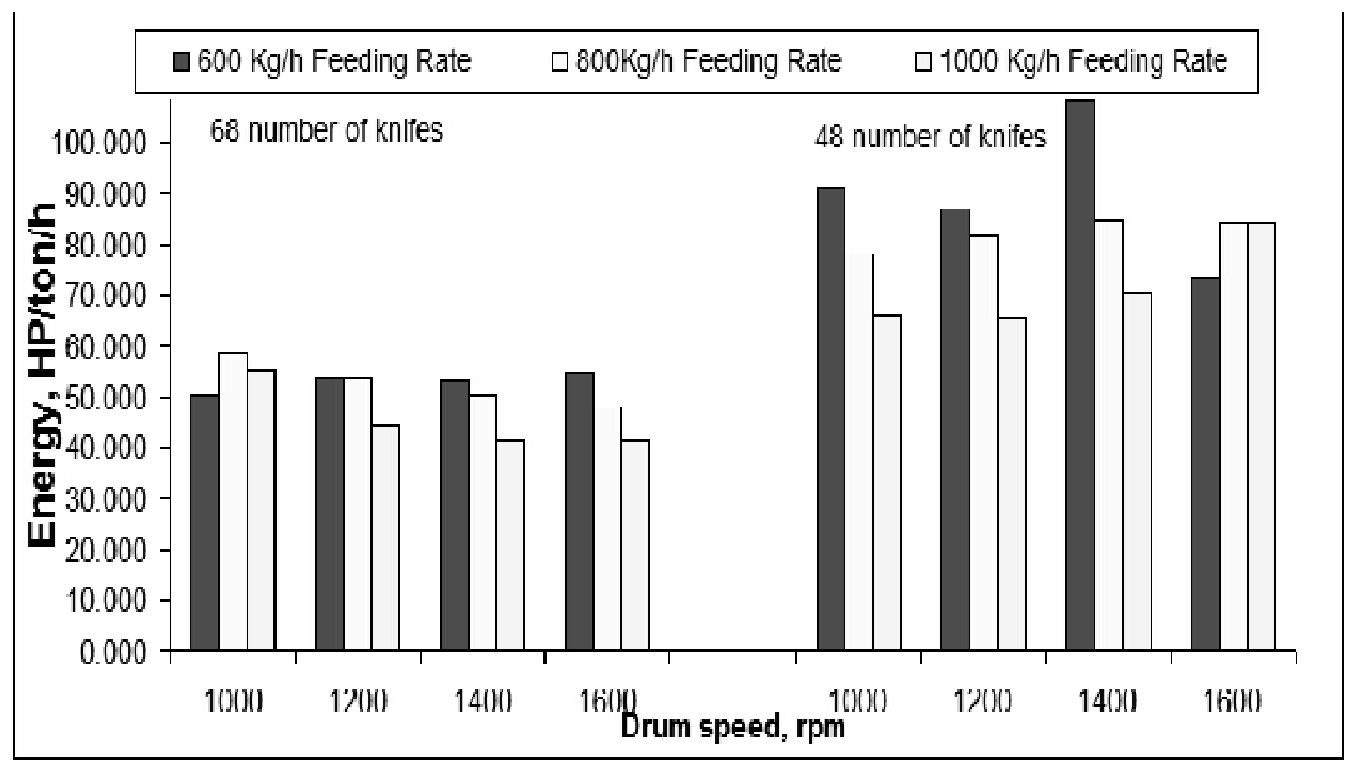

Fig. 9. The effect of drum speed feeding rate and number of knives on the power requirement.

The effects of drum speed, feeding rate, and number of knife on the energy (hP / ton.h):

Fig (10) shows the effects of drum speed, feeding rate, and number of knives on the energy. At 48 cutting knives and (600 \& $800 \&$ and $1000 \mathrm{~kg} / \mathrm{h}$ ) feeding rate, by increasing the drum speed from (1000 to $1600 \mathrm{rpm}$ ), the machine energy 90.942 to $73.062,78.110$ to 84.016 and from 66.171 to $84.016 \mathrm{HP} /$ ton/h), respectively.

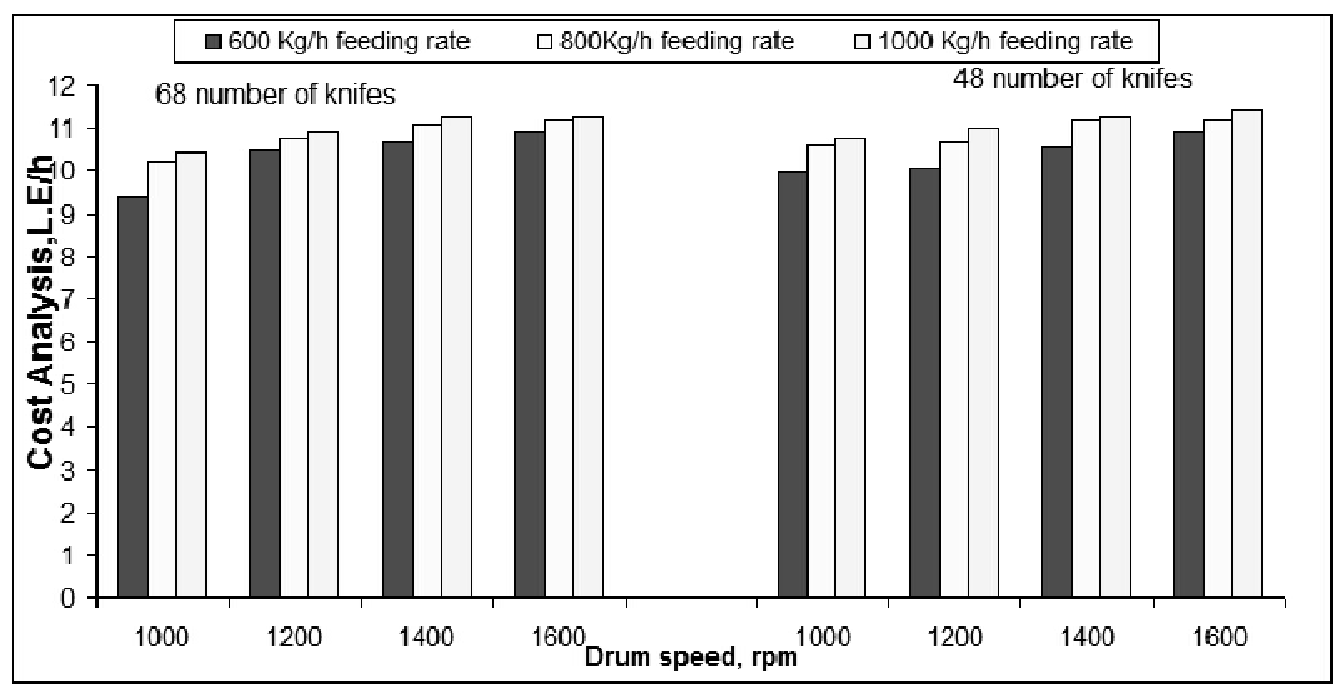

Fig. 10. The effect of drum speed, feeding rate and number of knives on the energy. 
Also the fig (10) clears lent the effects of drum speed, feeding rate, and number of knife on the energy. At (68) cutting knives and $(600 \& 800 \&$ and 1000 $\mathrm{kg} / \mathrm{h}$ ) feeding rates, by increasing the drum speed from (1000 to $1600 \mathrm{rpm}$ ), the machine energy is varied from 50.279 to 54.754 , from 58.676 to 48.091 , and from 55.241 to $41.548 \mathrm{HP} /$ ton/h), respectively.

From the relived data, machine energy was higher (107.872 HP/ton/h) using drum speed (1400 rpm) and number of knife (48) and (600 kg/h) feeding rate, meanwhile the lowest energy was (41.295 HP/ton/h) using drum speed (1400 rpm) and number of knife (68) and $(1000 \mathrm{~kg} / \mathrm{h})$ feeding rate.

\section{The effects of drum speed, feeding rate, and number of knife on the cost analysis}

Fig (12), indicates that the effects of drum speed, feeding rate, and number of knife on the cost analysis. At (48) cutting knives and (600 \& $800 \&$ and $1000 \mathrm{~kg} / \mathrm{h}$ ) feeding rate, by increasing the drum speed from 1000 to $1600 \mathrm{rpm}$, the machine cost analysis increased from (9.978 to 10.929 , from 10.612 to $11.166,10.770$ to 11.404 L.E/h), respectively.

Also the fig (12) clearest (68) cutting knives and (600 \& $800 \&$ and 1000 $\mathrm{kg} / \mathrm{h}$ ) feeding rate, by increasing the drum speed from (1000 to $1600 \mathrm{rpm}$ ), the machine cost increases from 9.397 to 10.929 , from 10.216 to 11.166 and from 10.422 to 11.245 L.E/h), respectively.

From the revealed data, machine cost analysis was higher (11.404 L.E/h) using drum speed (1600 r.p.m) and number of knife (48) and (1000 kg/h) feeding rate, meanwhile the lowest cost analysis was (9.397 L.E/h) using drum speed (1000 r.p.m) and number of knife (68) and (600 kg/h) feeding rate.

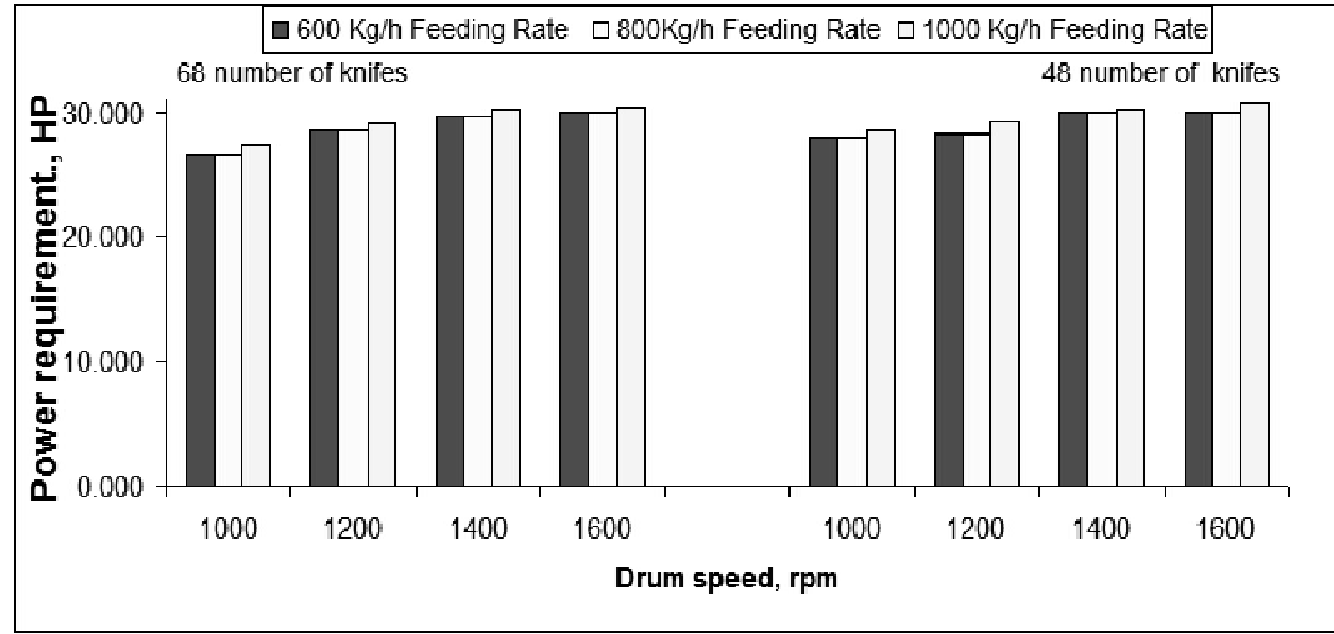

Fig. 12. The effect of drum speed, feeding rate and number of knives on the cost analysis. 


\section{CONCLUSION}

From the research, cutting machine which using is product the raw materials to use. The data which were collected produced the best drum speed, feeding rate and the number of knifes. These factors were suitable to use the cutting machine to prepare the haulm of potatoes. Use the haulm of potatoes preparing it by chopper machine. This ration used for different animal (rabets, dotes, crow and buffalo)

\section{REFERENCES}

1. Abd-EL-Mottalcb, A.F.and A.R.Obaia. 2006. Study manufacture of animal fodder from date palm leaves . J.Agric Sci. Mansoura University, 31 (7): 149-162, 2006.

2. ASAE standards. 1999. Standards Engineer practices Data. Adopted and published by American society of Agricultural Engineers.

3. Awady, M. N.; M. Shaaban; I. Yehia and M. S. Mira. 2001. Review on equipment industry for agricultural - residues management in Egypt. 9th conference of Miser Society of Ag. Eng., 96-108.

4. Baiomy, M.A.; M. H. A. Kabeel and E.M.Arif. 2007. Development and redesign of crop residue chopping machine. Agric Sci. Mansoura Univ., 32(9): 7307-7323.

5. El-Khateed, H.A. 2008. Performance evaluation of using rotary mower in cutting and chopping of corn stalks. Misr J. Agr. Eng., 18(3): 461-474.

6. El-Khateeb, H. A. and A. A. El-Keway. 2012. Development and evaluation of cutting knives to suit cutting wet and dry field residues J. Soil Sci. and Agric. Eng,. Mansoura Univ., 3(6):601-616.

7. Hanna, G.B.; Suleiman; A.E. Younis S.M. and Tabib A.Z. 1985. Evaluation of different mechanical methods of cotton stalks Removal. Misr J. Agr. Eng., 2(1): 325.

8. Helmy, M.A; A.A. Abd EL-Rhman; M.T. Ebaid and M.A. Hassan. 2003. Expectant production of biogas and fertilizer from different residues fermentation using biogas unit. Misr J.Ag.Eng., 20(4): 949-964.

9. Iya, S. A. 2005. Computer Modeling for Planning and Assessing Profitability of Mechanized Maize Production System in the Savanna Belt, Nigeria. PhD. Thesis, Department of Agricultural Engineering University of Ilorin. 
10. Lewis; M. J. 2000. Physical Properties of Foods and Food Processing Systems Wood head Publishers limited, England.

11. National Program Potato Cultivation Egypt. 2001. Holland and production of potatoes in the Arab Republic of Egypt and the Ministry of Agriculture Agricultural Research Center - Center for potato development and training Tanta.

12. Radwan, H. A. 2000. Development of small self driven untraditional feed - mill. Ph. D. Thesis, Fac. Agric., Moshtohor, Benhe University.

13. Tarek H.A. (2002): Development of a cop residues shredder. M. Sc. Agricultural Engineering Department, Cairo Univ. 


\section{استخدام الة تقطيع المخلفات لتجهيز عروش البطاطس كمادة خام}

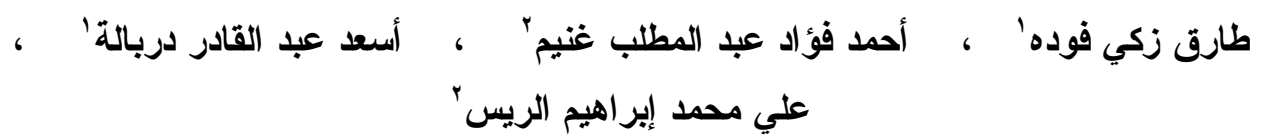

ا ـ قسم الميكنة الزراعية - كلية الزراعة - جامعة طنطا. r r معهُ بحوث الهندسة الزراعية - مركز البحوث الزراعية - الدقى - الجيزه.

تعثبر البطاطس من المحاصيل الخضر الرئيسية في مصر ويزرع منها سنويا في العــروات

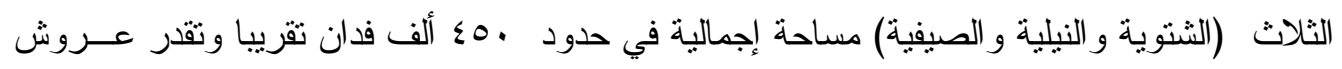

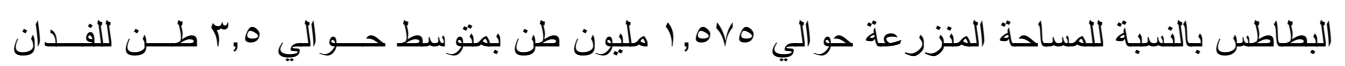

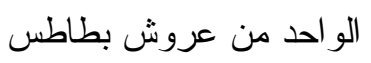

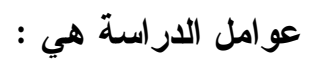

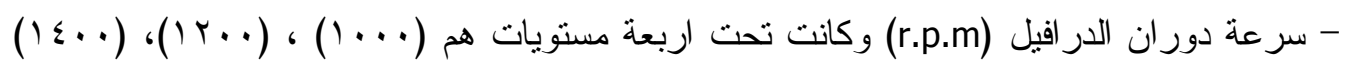

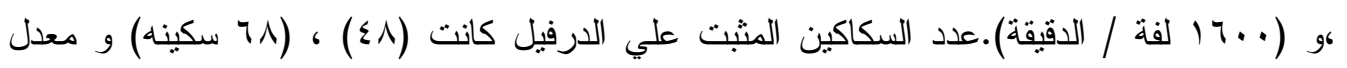

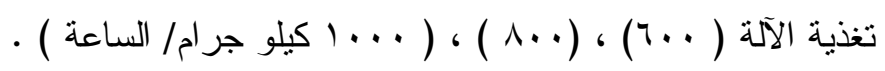

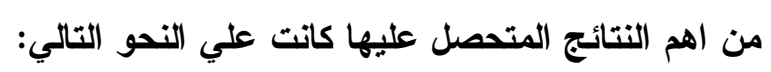

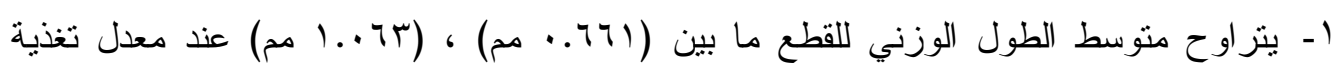

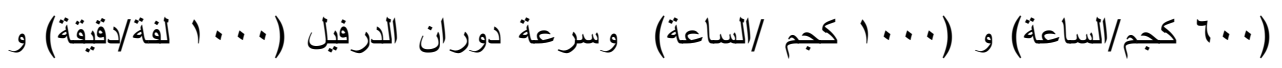

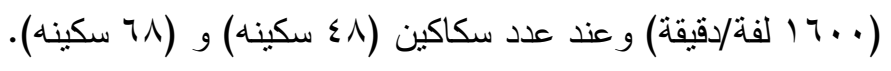

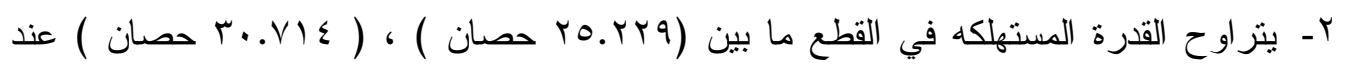

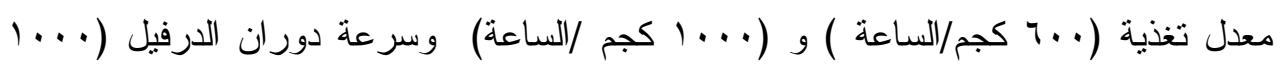
لفة/دقيقة) و ( ...7 آلفة/دقيقة) و عند عدد سكاكين (1/7 سكينه).

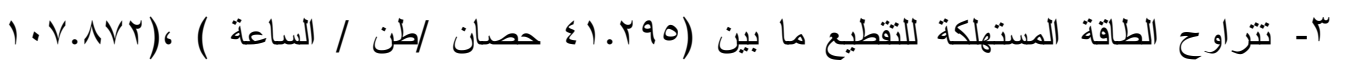

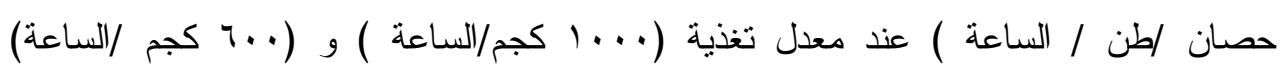

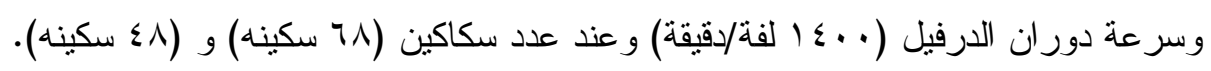

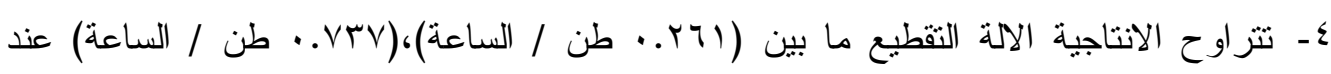

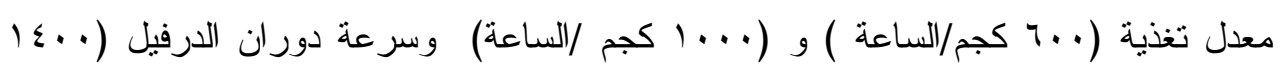

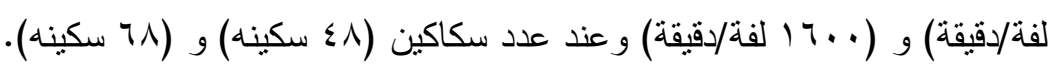

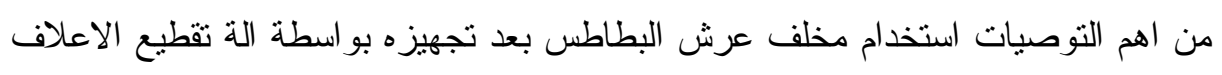

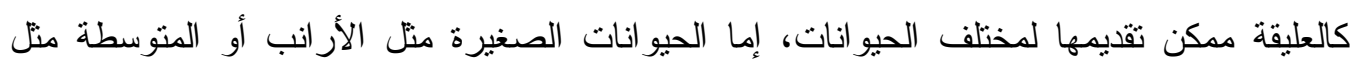
الماعز و الأغنام أو الحيو انات الكبيرة منل الأبقار و الجاموس. 